\title{
Pengaruh Beta, Asset Growth dan Inflasi Terhadap Abnormal Return (Studi Empiris pada Saham Perusahaan Jakarta Islamic Index)
}

Eneng Sugihyanty ${ }^{1}$

${ }^{1}$ Universitas Pancasila, Jl. Srengseng Sawah, Jagakarsa, Jakarta Selatan, 12640

I N F O A R T I K E L

JEL Classification:

$H 83$

M12

Keywords:

Abnormal Return,

Beta, Asset Growth,

Inflation

\section{A B S T R A C T}

This study aims to analyze the effect of Beta, Asset Growth and Inflation on Abnormal Return on Jakarta Islamic Indexs shares are listed on the Bursa Efek Indonesia during period 2007-2011. Based on the test results showed that all independent variables simultaneously consisting of beta, asset growth and inflation is positive and significant effect on the dependent variable is the abnormal return. While the results of the beta testing of the partial variables have positive and significant to the variable abnormal return. As for variables asset growth and inflation does not affect the variable abnormal return. This means that beta is a variable that better assess abnormal return of companies Jakarta Islamic Index.

\section{A B S T R A K}

Penelitian ini bertujuan untuk menganalisis pengaruh variable Beta, Asset Growth dan Inflasi terhadap Abnormal Return saham perusahaan Jakarta Islamic Index yang terdaftar di Bursa Efek Indonesia yang periode tahun 2007-2011. Yang menjadi obyek didalam penelitian ini adalah perusahaan JII yang terdaftar di Bursa Efek Indonesia sepanjang periode tahun 2007 sampai dengan tahun 2011. Berdasarkan hasil pengujian menunjukan bahwa secara simultan seluruh variabel bebas yang terdiri dari beta, asset growth dan inflasi berpengaruh positif dan signifikan terhadap variabel terikat yaitu abnormal return. Sedangkan hasil pengujian secara parsial variabel beta berpengaruh positif dan signifikan terhadap abnormal return. Sedangkan untuk variable asset growth dan inflasi tidak berpengaruh terhadap variabel abnormal return. Hal ini berarti beta merupakan variabel yang lebih baik dalam menilai abnormal return saham perusahaan Jakarta Islamic Index.

\section{Pendahuluan}

Pertumbuhan pasar modal ini dapat dijadikan sarana bagi pihak-pihak yang berkepentingan, misalnya: investor maupun pemerintah untuk memanfaatkannya secara optimal sehingga dapat membawa keuntungan bagi semua pihak. Investor sebelum melakukan investasi di bursa saham khususnya di Bursa Efek Indonesia, akan mengumpulkan sebanyak mungkin informasi yang berguna dalam pengambilan keputusan investasi tersebut. Seringkali pasar modal merupakan alternatif pendanaan ekstern dengan biaya yang lebih rendah daripada sistem perbankan. Di pihak lain investor bisa mendapatkan keuntungan melalui penanaman modal dengan cara pembelian saham yang diterbitkan oleh suatu perusahaan di pasar 
modal. Perubahan inflasi, kurs valuta asing, suku bunga, serta berbagai kebijakan ekonomi yang dikeluarkan pemerintah ikut berpengaruh pada perdagangan di pasar modal.

Investasi yang dilakukan oleh investor diasumsikan selalu didasarkan pada pertimbangan yang rasional sehingga berbagai jenis informasi diperlukan untuk pengambilan keputusan investasi. Hampir semua investasi mengandung unsur ketidakpastian atau risiko, investor tidak mengetahui dengan pasti hasil yang akan diperoleh dari investasi yang dilakukan. Dengan demikian, investor akan menghadapi risiko dalam investasinya. Investor hanya dapat memperkirakan berapa tingkat keuntungan yang diharapkan (expected return) dan seberapa jauh kemungkinan hasil yang sebenarnya nanti akan menyimpang dari hasil yang diharapkan. Apabila kesempatan investasi mempunyai tingkat risiko yang lebih tinggi, maka investor akan mensyaratkan tingkat keuntungan yang lebih tinggi pula.

Return dan risiko merupakan dua hal yang tidak terpisahkan, return dan risiko mempunyai hubungan yang positif, semakin besar risiko suatu sekuritas, semakin besar return yang diharapkan (Jogiyanto, 2010). Hal seperti inilah yang menjawab pertanyaan mengapa tidak semua investor hanya berinvestasi pada asset yang menawarkan tingkat return yang paling tinggi. Risiko sistematik merupakan hal penting yang dipertimbangkan investor sebelum melakukan keputusan investasi, sehingga informasi yang akurat mengenai risiko sistematik. Beta merupakan suatu pengukur volatilitas return suatu sekuritas atau return portofolio terhadap return pasar. Beta sekuritas-i mengukur volatilitas return sekuritas-i dengan return pasar, beta portofolio mengukur volatilitas return portofolio terhadap return pasar. Dengan demikian beta merupakan pengukur risiko sistematik dari suatu sekuritas atau portofolio relatif terhadap risiko pasar.

Pertumbuhan perusahaan semakin besar, maka besar pula laba yang dihasilkan, sehingga return yang akan didapat semakin besar. Asset growth menunjukkan pertumbuhan asset dimana asset merupakan aktiva yang digunakan untuk aktiva operasional perusahaan. Asset growth didefinisikan sebagai perubahan (tingkat pertumbuhan) tahunan dari aktiva total (Jogiyanto, 2010).

Inflasi yang tinggi biasanya dikaitkan dengan kondisi ekonomi yang terlalu panas. Dimana permintaan atas produk yang melebihi kapasitas penawaran produknya, sehingga harga-harga cenderung mengalami kenaikan. Tingginya inflasi menunjukkan bahwa risiko untuk melakukan investasi cukup besar sebab inflasi yang tinggi akan mengurangi return dari investor. Pada kondisi inflasi yang tinggi maka harga barang-barang cenderung untuk meningkat. Peningkatan harga barang-barang dan bahan baku akan membuat biaya produksi menjadi tinggi sehingga akan berpengaruh pada penurunan jumlah permintaan yang berakibat pada penurunan penjualan, sehingga hal ini mengurangi pendapatan perusahaan. Selanjutnya akan berakibat buruk pada kinerja perusahaan yang tercermin oleh turunnnya return saham. Dengan menurunnya return saham tersebut maka abnormal return akan diprediksikan menurun.

Untuk membuktikan dan menjelaskan bahwa beta saham dan varian return saham secara parsial signifikan terhadap return saham, hal ini konsisten dengan hasil penelitian dari Welly Utomo (2007). Ingin membuktikan dan menjelaskan Variabel Inflasi, nilai tukar dan DER berpengaruh negative dan signifikan terhadap return saham, sesuai dengan hasil penelitian Ratna Prihantini (2009). Dengan demikian maka beta, asset growth dan inflasi diprediksikan akan berpengaruh positif terhadap abnormal return. Dan masih banyak penelitian terdahulu yang telah dilakukan, diantaranya oleh Yunia Ekasari (2004), Nicky Nathaniel (2008), Soeratno (2008), Nadjibah (2008) serta Hendarsanto (2005). Suatu penelitian dikatakan mempunyai nilai relevansi terhadap masalah yang diteliti, jika penelitian tersebut mampu mencerminkan atau menggambarkan kondisi aktual pada objek penelitian, yang ditunjukkan dengan adanya penggambaran hubungan sebab akibat yang menjadi permasalahan pokok. 


\section{Telaah Teori dan Pengembangan Hipotesis}

\section{Teori Sinyal dan Keagenan}

MenurutWolk, etal. (dikutip oleh Jama'an, 2008) teori sinyal menjelaskan alasan perusahaan menyajikan informasi untuk pasar modal. Teori sinyal menunjukkan adanya asimetri informasi antara manajemen perusahaan dan pihak-pihak yang berkepentingan dengan informasi tersebut. Teori sinyal mengemukakan tentang bagaimana seharusnya perusahaan memberikan sinyal-sinyal pada pengguna laporan keuangan.

Teori agensi mengasumsikan bahwa semua individu bertindak atas kepentingan mereka sendiri. Pemegang saham sebagai principal diasumsikan hanya tertarik kepada hasil keuangan yang bertambah atau investasi mereka di dalam perusahaan. Sedang para agen disumsikan menerima kepuasan berupa kompensasi keuangan dan syarat-syarat yang menyertai dalam hubungan tersebut.

Perbedaan kepentingan ekonomis menyebabkan timbulnya informasi asmetri antara Pemegang Saham dan organisasi. Diskripsi bahwa manajer adalah agen bagi para pemegang saham atau dewan direksi adalah benar sesuai teori agensi. Karena perbedaan kepentingan ini masing-masing pihak berusaha memperbesar keuntungan bagi diri sendiri. Principal menginginkan pengembalian yang sebesarbesarnya dan secepatnya atas investasi dengan kenaikan porsi deviden dari tiap saham yang dimiliki. Agen menginginkan kepentingannya diakomodir dengan pemberian kompensasi/ bonus/insentif/ yang memadai dan sebesarbesarnya atas kinerjanya.

\section{Hubungan Beta dan Abnormal Return}

Studi peristiwa menganalisis return tidak normal (abnormal return) dari sekuritas yang mungkin terjadi di sekitar pengumuman dari suatu peristiwa. Abnormal return atau excess return merupakan kelebihan return adalah selisih antara return sesungguhnya yang terjadi dengan return ekspektasi (Jogiyanto, 2010).

Secara definisi beta merupakan pengukur risiko sistematik dari suatu sekuritas atau portofolio relatif terhadap laba pasar (Jogiyanto, 2010). Beta suatu sekuritas dapat dihitung dengan teknik estimasi yang menggunakan data historis, dan selanjutnya dapat digunakan untuk mengestimasibeta masa depan(Elton dan Gruber). Data historis yang digunakan untuk mengestimasi beta, berupa data pasar (return saham dan return pasar), data akuntansi (laba perusahaan dan laba indeks pasar) atau data fundamental (menggunakan variabel fundamental). Beta dapat diestimasi secara manual dengan memplot garis diantara titik-titik return atau dengan teknik regresi. Jika menggunakan teknik regresi, maka variabel dependennya adalah returnreturn sekuritas dan variabel independennya adalah return-return pasar. Persamaan regresi yang digunakan untuk mengestimasi beta dapat didasarkan pada model indeks tunggal atau model CAPM. Kelebihan dari beta return pasar ini adalah beta ini mengukur respon dari masingmasing sekuritas terhadap pergerakan pasar. Beta pasar ini dihitung berdasarkan hubungan data pasar dan tidak dihitung berdasarkan data karakteristik perusahaan seperti misalnya pembayaran dividen.

Beta sebagai komponen penting untuk mengestimasi return suatu saham tidak bersifat stationer dari waktu ke waktu, sehingga perlu disesuaikan dengan kondisi pasar. Apabila terjadi fluktuasi return-return saham, maka beta saham tersebut akan menunjukan return pasar bergerak naik (turun) dan return sahampun akan bergerak sama mengikuti return pasar. Hal ini berarti jika beta meningkat maka abnormal return saham juga akan meningkat atau sebaliknya.

\section{Hubungan Asset Growth dan Abnormal Return}

Manajer dalam bisnis perusahaan dengan memperhatikan pertumbuhan lebih menyukai untuk menginvestasikan pendapatan setelah pajak dan mengharapkan kinerja yang lebih baik dalam pertumbuhan perusahaan secara keseluruhan (Charitou dan Vafeas, 1998). Asset growth menunjukkan pertumbuhan asset, dimana pertumbuhan perusahaan semakin besar, maka besar pula laba yang dihasilkan. 
Peningkatan hasil operasi yang mengikuti Asset Growth akan semakin menambah kepercayaan pihak luar terhadap manajemen perusahaan. Dengan meningkatnya kepercayaan pihak luar (investor) terhadap perusahaan, maka semakin banyak investor yang akan berinvestasi dan harga sahampun akan meningkat.

Semakin besar asset diharapkan semakin besar hasil operasional yang dihasilkkan oleh perusahaan. Pertumbuhan perusahaan semakin besar, maka besar pula laba yang dihasilkan, sehingga return yang akan didapat semakin besar. Maka semakin besar return tersebut abnormal return diprediksikan akan semakin meningkat.

\section{Hubungan Inflasi dan Abnormal Return}

Inflasi juga menimbulkan efek sangat luas dan beraneka ragam serta menurunkan tingkat kesejahteraan hidup masyarakat. Laju tingkat pertumbuhan inflasi yang tinggi akan merusak struktur ekonomi dan melemahkan kinerja perekonomian suatu negara. Inflasi yang tinggi biasanya dikaitkan dengan kondisi ekonomi yang terlalu panas. Artinya kondisi ekonomi mengalami permintaan atas produk yang melebihi kapasitas penawaran produknya, sehingga harga-harga cenderung mengalami kenaikan. Inflasi yang terlalu tinggi juga akan menyebabkan penurunan daya beli uang. Di samping itu inflasi yang tinggi juga bisa mengurangi tingkat pendapatan riil yang diperoleh investor dari investasinya. Sebaliknya jika inflasi suatu negara mengalami penurunan, maka hal ini akan merupakan sinyal yang positif bagi investor seiring dengan turunnya risiko daya beli uang dan risiko penurunan pendapatan riil (Tandelilin, 2010). Jadi inflasi yang tinggi menyebabkan menurunnya keuntungan suatu perusahan.

Inflasi yang tinggi menunjukkan risiko untuk melakukan investasi cukup besar, sebab inflasi yang tinggi akan mengurangi return dari investor. Pada kondisi inflasi yang tinggi maka harga barang-barang cenderung meningkat. Dengan harga yang meningkat maka akan membuat biaya produksi menjadi tinggi, sehingga berpengaruh pada penurunan jumlah permintaan. Hal ini akan berakibat pada penurunan penjualan dan mengakibatkankan mengurangi pendapatan. Sehingga akan menurunkan kinerja perusahaan, maka return sahampun akan turun. Dengan menurunnya return saham tersebut maka abnormal return akan diprediksikan menurun. Kebijakan yang dapat diambil untuk menghadapi inflasi tentunya harus diatasi oleh pemerintah dan otoritas monoter dengan cara melakukan beberapa kebijakan yang menyangkut bidang moneter, fiskal dan non moneter.

\section{Metode}

Penelitian ini menggunakan teknik pengambilan sampel secara Purposive Sampling, dimana peneliti memiliki perimbangan tertentu terhadap sampel. Sampel digunakan dalam penelitian ini apabila memenuhi kriteria sebagai berikut:

Data yang digunakan dasar penghitungan adalah data tahunan, baik untuk return saham, harga saham, maupun indeks harga saham selama periode yang diteliti. Data harga saham tahunan yang digunakan adalah periode tahun 2007-2011 dengan harga saham penutupan (closing price) dan menggunakan data time series selama 5 tahun periode pengamatan. Perusahaan yang digunakan dalam penelitian ini adalah sahamnya yang secara terus menerus terdaftar pada JII selama periode penelitian. Perusahaan yang tercatat sebagai indeks saham JII pada kurun waktu penelitian (2007 - 2011) yang secara terus menerus terdaftar sebanyak 12 perusahaan.

Pengumpulan data dimulai dengan tahap penelitian pendahuluan, yaitu mengumpulkan data dengan cara dokumentasi dari berbagai sumber yang diolah. Melakukan studi kepustakaan dengan mempelajari buku-buku dan literatur, jurnaljurnal ekonomi dan bisnis, website perusahaan dan bacaan lain yang berhubungan dengan pasar modal, serta releva dengan penelitian untuk dijadikan referensi. Metode pengumpulan data menggunakan dokumentasi. Data merupakan data sekunder karena data diperoleh dengan mengambil dari data Bursa Efek Indonesia (BEI).

Penelitian ini menggunakan metode 
deskriptif kuantitatif. Metode deskriptif digunakan menjelaskan variabel-variabel penelitian apa adanya sesuai dengan data yang diperoleh, sedangkan metode kuantitatif digunakan untuk mengetahui pengaruh antara variabel independen terhadap variabel dependen dan untuk mengetahui melakukan uji beda. Variable independen terdiri dari beta, asset growth dan inflasi. Sedangkan variable dependen adalah abnormal return. Analisis kuantitatif ini dilakukan dengan menggunakan teknik statistik.

Hubungan tersebut dapat dijabarkan dalam bentuk persamaan yang menghubungkan variabel dependen (Y) dengan variabel independen $\left(\mathrm{X}_{1}, \mathrm{X}_{2}\right.$ dan $\left.\mathrm{X}_{3}\right)$. Model regresi berganda tersebut adalah sebagai berikut:

$\mathrm{Y}=\mathrm{a}+\mathrm{b}_{1} \mathrm{X}_{1}+\mathrm{b}_{2} \mathrm{X}_{2}+\mathrm{b}_{3} \mathrm{X}_{3}+\mathrm{e}$

Keterangan:

$$
\begin{aligned}
& \mathrm{Y}=\text { Abnormal Return } \\
& \mathrm{a}=\text { Konstanta } \\
& \mathrm{b}=\text { Koefisien Regresi } \\
& \mathrm{X}_{1}=\text { Beta } \\
& \mathrm{X}_{2}=\text { Asset Growth } \\
& \mathrm{X}_{3}=\text { Inflasi } \\
& \mathrm{e}=\text { Variabel lain di luar model }
\end{aligned}
$$

Analisa yang digunakan adalah analisis regresi linier berganda. Sebagai dasar analisis, nilai koefisien regresi sangat berarti. Apabila menunjukan hubungan yang searah antara variabel independen dan variabel dependen, maka koefisien $\mathrm{b}$ akan bernilai positif $(+)$. Yang berarti setiap kenaikan variabel independen akan mengakibatkan kenaikan variabel dependen dan sebaliknya.

Untuk memenuhi syarat penggunaan model regresi linier berganda, maka dilakukan pengujian beberapa asumsi klasik yang digunakan yaitu: uji normalitas dilakukan agar sampel terdistribusi normal. Sedangkan Uji multikolinearitas dapatdilakukanagartidakterjadi multikolinearitas antara variabel independen. Untuk menguji apakah dalam model regresi terjadi ketidaksamaan variance dari residual satu pengamatan ke pengamatan lain dilakukan uji heteroskedastisitas dan uji autokorelasi antar komponen penggaggu.

Goodness of fit digununakan untuk mengukur ketepatan fungsi regresi dalam menganalisa nilai aktual. Diharapkan ini dapat diukur secara statistik, dari nilai statistik t, nilai satistik F serta nilai koefisien determinansi. Secara statistik disebut tidak signifikan apabila uji nilai statistiknya berada dalam daerah dimana Ho diterima dan disebut signifikan, apabila uji nilai statistiknya berada dalam daerah kritis (daerah dimana Ho ditolak).

\section{Hasil Penelitian dan Pembahasan}

Penelitian ini bertujuan menguji inflasi, beta, dan pertumbuhan aset terhadap abnormal return. Deskripsi variabel yang diteliti sebagaimana tabel 1. Pengujian normalitas data secara analisis statistik dilakukan dengan Uji Kolmogorov-Smirnov. Data yang berdistribusi normal ditunjukkan dengan nilai signifikansi di atas 0,05 (Ghozali, 2011). Hasil pengujian normalitas pada pengujian terhadap 60 data terlihat dalam tabel 2 menunjukkan bahwa data berdistribusi normal. Hal ini ditunjukan dengan nilai Kolmogorov-Smirnov semua variable diatas 0,05 dan tidak signifikan pada 0,05 . Jadi dengan kata lain residual berdistribusi normal. Untuk mengetahui apakah terjadi multikolinearitas dapat dilihat dari nilai Variance Inflation Factor (VIF) yang terdapat pada masing-masing variabel seperti terlihat pada tabel 3. Uji multikolinearitas bertujuan untuk menguji apakah model regresi ditemukan adanya korelasi antar variabel bebas. Suatu model regresi dinyatakan bebas dari multikolinearitas adalah jika mempunyai nilai Tolerance lebih besar dari 0,1 dan nilai VIF lebih kecil dari 10. Berdassemua variabel independen beta, asset growth maupun inflasi memiliki nilai Tolerance berada diatas 0,1 dengan nilai VIF di bawah angka 10. Dengan demikian dapat dikatakan tidak ada masalah multikolinieritas. Uji heteroskedastisitas, menunjukangrafik scatterplot terlihat bahwa titik-titik menyebar secara acak serta tersebar baik diatas maupun dibawah angka 0 pada sumbu Y. Bila kondisi ini terpenuhi maka dengan demikian dapat disimpulkan bahwa model 
regresi ini tidak terjadi heteroskedastisitas. Untuk menguji apakah dalam model regresi linear ada korelasi antara kesalahan pengganggu pada periode t-1 (sebelumnya), maka dilakukan dengan uji autokorelasi. Menurut Ghozali (2011), model regresi yang baik adalah regresi yang bebas dari autokorelasi. Uji autokorelasi dalam penelitian ini dengan menggunakan besaran Durbin-Watson (DW test), dengan level of significance 0,05 $(\alpha=0,05)$ dan jumlah variabel bebas $(k=3)$ dan banyaknya data $(n=60)$. Untuk mengetahui ada tidaknya autokorelasi dapat dilihat dengan uji Durbin-Watson. Hasil analisis regresi diperoleh nilai hitung Durbin Watson sebesar 1,728. Maka diperoleh nilai dl (batas bawah) =1,479; du (batas atas) $=1,688$. Sehingga nilai $4-\mathrm{du}=2,311$; dan 4 $-\mathrm{dl}=2,520$. maka dari perhitungan disimpulkan tidak terdapat autokorelasi antar residual atau DW-test terletak pada daerah uji.

Pengujian terkait seberapa jauh kemampuan model dalam menerangkan variasi variabel dependennya maka dilakukan dengan menggunakan uji determinasi (R2). Nilai $\mathrm{R}^{2}$ yang mendekati satu berarti variabel-variabel independennya memberikan hampir semua informasi yang dibutuhkan untuk memprediksi variasi variabel dependen. Dapatterlihat pada tabel 2 hasil dari perhitungan Koefisien Determinasi penelitian ini. Dari hasil perhitungan diperoleh besarnya pengaruh variabel independen terhadap variabel dependen yang dapat diterangkan oleh model persamaan ini adalah sebesar 0,369. Hal ini menunjukkan bahwa besar pengaruh variabel beta, asset growth, dan inflasi terhadap abnormal return saham yang dapat diterangkan oleh model persamaan ini adalah sebesar $36,9 \%$ dan sisanya sebesar $63,1 \%$ dipengaruhi oleh faktor-faktor lain yang tidak dimasukkan dalam model regresi. Dari hasil regresi diatas dapat dilihat nilai standard error 0,26811 , hal ini berarti banyaknya

Tabel 1. Analisis Deskriptif kesalahan dalam memprediksi abnormal return adalah sebesar 26,8\%. Pada dasarnya Uji statistik F menunjukkan apakah semua variable independen yang dimasukkan dalam model mempunyai pengaruh secara simultan terhadap variabel dependennya. Hasil perhitungan Uji F ini dapat dilihat pada tabel 3. Dari hasil analisis regresi dapat diketahui pula bahwa secara bersama-sama variabel independen memiliki pengaruh yang signifikan terhadapq variable dependen. Dengan nilai F hitung sebesar 2,948 hal ini sudah membuktikan dan signifikan pada 0,040. Karena probabilitas lebih kecil dari 0,05 atau 5\%, maka model regresi dapat digunakan untuk memprediksi abnormal return atau dapat dikatakan bahwa variabel independen beta, asset growth dan inflasi secara simultan mempengaruhi variabel abnormal return.

Untuk menganalisis pengaruh masingmasing variabel Beta, asset growth dan inflasi terhadap abnormal return dengan tingkat signifikansi 0,05 maka menggunakan uji t. Apabila t hitung < tingkat signifikansi, maka terdapat pengaruh yang signifikan dari variabel bebas terhadap variabel terikat. Sebaliknya apabila nilai t hitung > tingkat signifikansi, maka tidak terdapat pengaruh yang signifikan dari variabel bebas tersebut terhadap variabel terikat. Pada tabel 4 dapat dilihat hasil perhitungan analisis regresi guna menguji hipotesis-hipotesis yang diajukan dalam penelitian ini. Dari hasil analisis regresi diatas, tampak bahwa variabel independen yaitu beta berpengaruh signifikan terhadap variabel dependen yaitu abnormal return, dengan tingkat signifikasi sebesar 0,012. Sedangkan variabel asset growth dan inflasi memiliki pengaruh tidak signifikan terhadap variabel abnormal return, hal ini dikarenakan nilai Sig t variabel asset growth dan inflasi masing-masing sebesar 0,913 dan 0,145 lebih besar dari tingkat signifikasi sebesar 0,05 .

\begin{tabular}{llcccc}
\hline \multicolumn{1}{c}{ Variabel } & $\mathbf{N}$ & Minimum & Maximum & Mean & Std. Deviation \\
\hline ABNORMAL_RETURN & 60 & 01 & 1,17 &, 2930 &, 28107 \\
BETA & 60 & $-2,38$ & 6,98 & 1,3188 & 1,69536 \\
ASSET_GROWTH & 60 &,- 16 &, 76 &, 1613 &, 15446 \\
INFLASI & 60 & 2,41 & 12,14 & 6,4225 & 2,57666 \\
\hline
\end{tabular}


Tabel 2. Hasil Uji Normalitas

One-Sample Kolmogorov-Smirnov Test

\begin{tabular}{llcccc}
\hline & & Abnormal_Return & Beta & Asset_Growth & Inflasi \\
\hline $\mathrm{N}$ & & 60 & 60 & 60 & 60 \\
Normal Parametersa,b & Mean &, 2930 & 1,3188 &, 1613 & 6,4225 \\
& Std. Deviation &, 28107 & 1,69536 &, 15446 & 2,57666 \\
Most Extreme & Absolute &, 173 &, 065 &, 135 &, 142 \\
Differences & Positive &, 173 &, 065 &, 135 &, 142 \\
& Negative &,- 157 & $-, 0,55$ &,- 094 &,- 080 \\
Kolmogorov-Smirnov Z & & 1,339 &, 506 & 1,049 & 1,097 \\
Asymp.Sig. (2-tailed) &, 055 &, 960 &, 221 &, 180 \\
\hline a Test distribution is Normal & & & & \\
b. Calculates from data & & & & &
\end{tabular}

Tabel 3. Hasil Uji Multikolinearitas

Coefficients $^{\mathrm{a}}$

\begin{tabular}{|c|c|c|c|c|c|c|c|c|}
\hline \multirow{2}{*}{\multicolumn{2}{|c|}{ Model }} & \multicolumn{2}{|c|}{$\begin{array}{c}\text { Unstandardized } \\
\text { Coefficients }\end{array}$} & \multirow{2}{*}{$\begin{array}{c}\text { Standardized } \\
\text { Coefficient } \\
\text { s } \\
\text { Beta }\end{array}$} & \multirow{2}{*}{$\mathrm{t}$} & \multirow{2}{*}{ Sig. } & \multicolumn{2}{|c|}{$\begin{array}{l}\text { Collinearity } \\
\text { Statistics }\end{array}$} \\
\hline & & B & Std. Error & & & & Tollerance & VIF \\
\hline \multirow[t]{5}{*}{1} & (Constant) &, 084 & ,099 & &, 850 & ,399 & & \\
\hline & BETA &, 053 & ,021 &, 322 & 2,588 & ,012 & ,998 & 1,002 \\
\hline & $\mathrm{ASSET}_{-}$ &, 026 & ,236 & ,014 &, 110 & ,913 & ,920 & 1,087 \\
\hline & GROWTH & & & & & & & \\
\hline & INFLASI &, 021 &, 014 & ,191 & 1,476 &, 145 & ,918 & 1,089 \\
\hline
\end{tabular}

a. Dependent Variable: ABNORMAL_RETURN

Tabel 4. Hasil Uji t

\begin{tabular}{|c|c|c|c|c|c|c|}
\hline \multicolumn{2}{|c|}{ Model } & \multicolumn{3}{|c|}{ Standardized } & \multirow{3}{*}{$\mathrm{t}$} & \multirow{3}{*}{ Sig } \\
\hline & & \multicolumn{2}{|c|}{$\begin{array}{l}\text { Unstandardized } \\
\text { Coefficients }\end{array}$} & Coefficients & & \\
\hline & & B & Std. Error & Beta & & \\
\hline 1 & (Constant) & ,084 &, 099 & &, 850 &, 399 \\
\hline & BETA &, 053 &, 021 &, 322 & 2,588 & 012 \\
\hline & $\begin{array}{l}\text { ASSET } \\
\text { GROWT̄H }\end{array}$ & ,026 & ,236 & ,014 &, 110 & ,913 \\
\hline & INFLASI &, 021 & ,014 & ,191 & 1,476 &, 145 \\
\hline
\end{tabular}

a. Dependent Variable: ABNORMAL_RETURN

Hasil regresi data uji t yang diperoleh dapat disusun persamaan regresi linear berganda sebagai berikut : $\mathrm{Y}=0,084+0,053 \mathrm{BETA}+0,026 \mathrm{AG}+0,021 \mathrm{INF}$
Persamaan regresi di atas dapat diinterprestasikan sebagai berikut:

Dengan konstanta sebesar 0,084 menyatakan jika variabel independen dianggap konstan sama dengan 0 (nol), maka abnormal return nilainya sebesar 0,084 atau $8,4 \%$.Beta 
dengan nilai koefisien regresi sebesar 0,053 menyatakan bahwa setiap penambahan beta sebesar 1\%, akan menaikan abnormal return sebesar 0,053 atau 5,3\%. Asset growth dengan nilai koefisien regresi sebesar 0,026 menyatakan bahwa setiap pertumbuhan asset growth sebesar $1 \%$ akan meningkatkan abnormal return sebesar 0,026 atau 2,6\%. Inflasi dengan nilai koefisien regresi inflasi adalah sebesar 0,021 menyatakan bahwa setiap penambahan inflasi sebesar $1 \%$ maka akan abnormal return akan mengalami kenaikan sebesar 0,021 atau 2,1\%. Semakin tinggi inflasi maka abnormal return akan meningkat.

Berdasarkan hasil penelitian yang telah dilakukan dengan menggunakan analisis regresi pada hipotesis pertama selama periode 20072011 menunjukan bahwa pengaruh dari seluruh variabel bebas yang terdiri dari beta, asset growth dan inflasi secara simultan berpengaruh terhadap variabel terikat yaitu abnormal return. Hal ini didasarkan pada penelitian hasil uji $\mathrm{F}$ yang memberikan informasi bahwa nilai $\mathrm{F}$ hitung $>$ F tabel $(2,948>2,77)$, maka Ha diterima dan Ho ditolak.

Dari hasil penelitian yang telah dilakukan dengan menggunakan analisis regresi pada hipotesis kedua selama periode 2007-2011 menunjukan bahwa beta berpengaruh signifikan terhadap abnormal return. Dengan didasarkan pada hasil uji $t$ yang diperoleh nilai $t$ hitung untuk beta lebih besar dari $t$ tabel $(2,588>1,673)$, maka Ha diterima dan Ho ditolak. Hal ini berarti bahwa beta berpengaruh positif dan signifikan terhadap abnormal return. Semakin tinggi beta, semakin tinggi abnormal return dan sebaliknya. Hasil temuan ini mendukung hasil penelitian dari Welly Utomo (2007), dimana hasil penelitiannya menunjukkan bahwa bahwa variabel beta saham dan varian return saham secara parsial signifikan terhadap return saham. Bertolak belakang dengan penelitian Fama dan French (1992) yang menunjukkan bahwa beta pasar tidak berpengaruh terhadap return.

Berdasarkan pada hasil penelitian yang telah dilakukan dengan menggunakan analisis regresi pada hipotesis ketiga selama periode 2007-2011 menunjukan bahwa asset growth tidak berpengaruh positif dan signifikan terhadap abnormal return. Hasil uji t dengan pengujian dua sisi, maka diperoleh nilai thitung $<\mathrm{t}$ tabel $(0,110<$ 1,673), maka Ha ditolak dan Ho diterima. Hal ini berarti bahwa secara parsial variabel asset growth tidak berpengaruh terhadap abnormal return.

Hasil penelitian ini sejalan dengan penelitian yang dilakukan oleh $\mathrm{Abu}$ Amrin (2009) menunjukan bahwa asset growth tidak berpengaruh signifikan terhadap return. Namun hasil penelitian ini bertolak belakang dengan hasil penelitian Kurniati, Endang (2003) menunjukan bahwa asset growth memiliki pengaruh positif yang signifikan terhadap retun. Hal ini memberikan implikasi bahwa investor dapat membeli saham perusahaan yang memiliki pertumbuhan aset yang tinggi karena mampu memberikan return yang lebih tinggi.

Hasil penelitian yang telah dilakukan dengan menggunakan analisis regresi pada hipotesis keempat selama periode 2007-2011 menunjukan bahwa inflasi tidak berpengaruh positif terhadap abnormal return. Hal ini didasarkan pada hasil penelitian uji $t$ yang diperoleh nilai $\mathrm{t}$ hitung $<\mathrm{t}$ tabel $(1,476<1,673)$, maka Ha ditolak dan Ho diterima. Dengan demikian hipotesis keempat yang menyatakan bahwa variabel inflasi berpengaruh positif terhadap abnormal return tidak dapat diterima. Hal ini berarti bahwa secara parsial variabel inflasi tidak berpengaruh terhadap abnormal return. Hasil penelitian ini konsistensi dengan hasil penelitian dari Ratna Prihantini (2009) menunjukkan bahwa variabel inflasi berpengaruh negatif dan signifikan terhadap Return Saham. Sedangkan Boudoukh and Richardson (1993) menunjukkan bahwa inflasi berpengaruh positif dan signifikan terhadap return saham.

\section{Simpulan, Keterbatasan dan Implikasi Hasil Penelitian}

Berdasarkan hasil penelitian dan pembahasan mengenai pengaruh variable beta, asset growth dan inflasi terhadap abnormal return, maka dapat ditarik beberapa kesimpulan, yaitu: 
1. Secara simultan seluruh variabel independen yang terdiri dari beta, asset growth dan inflasi menunjukan pengaruh positif dan signifikan terhadap variabel dependen yaitu abnormal return.

2. Hasil pengujian parsial variable beta berpengaruh positif dan signifikan terhadap variabel abnormal return. Sedangkan variable asset growth dan inflasi tidak berpengaruh dan tidak signifikan terhadap variabel abnormal return.

Keterbatasandalampenelitianini memiliki sampel yang sedikit akibat adanya persyaratan sampel harus dipenuhi untuk mendapatkan hasil analisis yang lebih baik. Periode penelitian yang pendek menyebabkan jumlah pengamatan yang dilakukan tidak telalu banyak.Jenis perusahaan yang digunakan dalam sampel penelitian ini hanya terbatas pada perusahaan Jakarta Islamic Index, sehingga belum dapat mencerminkan hasil dari perusahaan yang terdaftar di Bursa efek Indonesia. Serta untuk variabel independen hanya diwakili oleh variabel beta dan asset growth. Masih banyak variabel akuntansi lainnya yang dapat memberikan pengaruh terhadap abnormal return.

Perlu dilakukan perluasan penelitian yang menghubungkan antara variabel makro ekonomi dan non ekonomi terhadap abnormal return. Variabel makro ekonomi yang mungkin berpengaruh terhadap return antara lain: tingkat bunga, kurs rupiah terhadap valuta asing, neraca pembayaran, ekspor-impor dan kondisi ekonomi lainnya, serta variabel non ekonomi seperti kondisi politik negara. Serta hasil penelitian ini menunjukkan perlunya faktor fundamental yang lain seperti likuiditas, solvabilitas dan aktivitas perusahaan dimasukkan sebagai prediktor dalam memprediksi abnormal return.

\section{Daftar Rujukan}

Abu Amrin. 2009. Pengaruh Asset Growth, Leverage dan Return On Invesment Terhadap Return Saham. Skripsi UIN Sunan Kalijaga, Yogyakarta.

Andreas Charitou, Nikos Vafeas. 1998. The
Assosiation Beetween Operating cash flows And Dividens Changes an Empirical Investigation. Journal of Business Finance \& Accounting.

Ang, Robert. 1997. Buku Pintar : Pasar Modal Indonesia. First Edition, Mediasoft Indonesia.

Boudoukh, J. dan Richardson, M. (1993) Stock Returns and Inflation: A LongHorizon Perspective. American Economics Review. Elton dan Gruber. 1995. Modern Portofolio :

Theory and Investment Analysis. 5th edition. New York : Wiley.

Fama, Eugene dan Kenneth French. 1992. The

Cross Section of Exfected stock Return. Jounal of finance.

Hendarsanto, Prasasto. 2005. Analisis Pengaruh MVA, debt To Equity, Trading day, Trading Volume dan ROA Terhadap Return Saham. Tesis Program Pascasarjana Universitas Diponegoro. Semarang.

Imam Ghozali, 2011. Aplikasi Analisis Multivariate dengan Program IBM SPSS 19. Edisi 5, Badan Penerbit Universitas Diponegoro. Semarang.

Jogiyanto Hartono, 2010. Teori Portofolio dan Analisis Inverstasi. Fakultas Ekonomi dan Bisnis UGM. Yogyakarta.

Jama'an, 2008. Pengaruh Mekanisme Corporate Governance, dan Kualitas Kantor Akuntan Publik terhadap Intergritas Informasi Laporan Keuangan. Universitas Diponegoro, Semarang.

Kurniati, Endang. 2003. Analisis Pengaruh Dividend Payout Ratio, Current Ratio, Pertumbuhan Asset dan Leverage terhadap Return Saham. Tesis, Universitas Diponegoro, Semarang.

Nadjibah. 2008. Analisis Pengaruh Asset Growth, Size, Cash Rratio dan Return on Asset Terhadap Deviden Payout Ratio. Studi Pada Perusahaan Asuransi di BEJ Tahun 2000-2006. Tesis, Program Pasca Sarjana Universitas Diponegoro, Semarang.

Nicky Nathaniel. 2008. Analisis Faktor-Faktor yang Mempengaruhi Return Saham. Universitas Diponogoro: Semarang. 
Ratna Prihantini. 2009. Analisis Pengaruh Inflasi, Nilai Tukar, ROA, DER dan CR Terhadap Return Saham, Tesis Magister Managemen Universitas Diponogoro, Semarang.

Suratno. 2008. Analisis Korelasi antara FaktorFaktor Fundamental dengan Beta. Jakarta

Tandelilin, Eduardus. 2010. Analisis Investasi dan Management Portofolio. Edisi Revisi, BPFE-Yogyakarta.

Welly Utomo. 2007. Analisis Pengaruh Beta dan Varian Return Saham Terhadap Return Saham. Studi Pada Perusahaan LQ 45 di BEJ Tahun 2005. Tesis, Program Pasca Sarjana universitas Diponegoro, Semarang.

www. idx.co.id, Bursa Efek Indonesia

Yunia Ekasari. 2004. Pengaruh Stock Split dan Likuiditas Saham pada Perusahaan LQ-45 terhadap Abnormal Return. Semarang Yahoo Finance.com, Composite Index (^JKSE) 